\title{
Verbally Aggressive Instructors and Machiavellian Students: Is the Socio-Communicative Style an Over-Bridging?
}

\author{
Alexandra Bekiari \\ Faculty of Physical Education and Sports Science, University of Thessaly, Trikala, Greece \\ Email: sandrab@pe.uth.gr
}

How to cite this paper: Bekiari, A. (2017). Verbally Aggressive Instructors and Machiavellian Students: Is the Socio-Communicative Style an Over-Bridging? Psychology, 8, 1437-1454.

https://doi.org/10.4236/psych.2017.810095

Received: June 24, 2017

Accepted: July 29, 2017

Published: August 1, 2017

Copyright $\odot 2017$ by author and Scientific Research Publishing Inc. This work is licensed under the Creative Commons Attribution International License (CC BY 4.0).

http://creativecommons.org/licenses/by/4.0/ (c) (i) Open Access

\begin{abstract}
Goals of this research are: 1) to examine the role of gender, 2) to explore the relationship between perceived instructors' verbal aggressiveness, socio-communicative style and students' Machiavellian tactics, 3) to investigate the influence of instructors' verbal aggressiveness on their socio-communicative style and students' Machiavellian tactics in physical education context and 4) to propose a students' and instructors' typology which will be the final overbridging of verbal aggressiveness and Machiavellianism through communication style. The sample consisted of 269 students (141 males, 128 females) aged 12 - 14 years old $(M=12.6, S D=0.65)$ from secondary public schools who completed three types of questionnaires during physical education classes. The results supported the internal consistency of the instruments. According to the results of the study, statistically significant differences were observed in perceived instructors' verbal aggressiveness, responsiveness, assertiveness and students' amoral manipulation, desire for control, desire for status, distrust of others between the genders of the students. Correlational analysis indicated that perceived instructors' verbal aggressiveness was positively related to assertiveness, amoral manipulation, desire for control, desire for status, distrust of others and was negatively related to responsiveness. The results of regression analysis revealed that perceived instructors' verbal aggressiveness could significantly predict the variables of responsiveness, assertiveness, desire for status and distrust of others. Three behavioral types are revealed: 1) the unrestraint, 2) the responsive, and 3) the distrustful, where verbal aggressiveness appears to be connected with Machiavellianism through communication style in these particular combinations.
\end{abstract}

\section{Keywords}

Verbal Aggressiveness, Socio-Communicative Style, Machiavellianism 


\section{Introduction}

The perception of everyday communication is unpredictable. Thereby, it can sometimes be regarded as aggressive by particular individuals and by some others not. Verbally aggressive individuals are supposed to intend to cause psychological pain (humiliation, embarrassment, etc.), which sometimes leads in physical attack (Piko \& Keresztes, 2006). Verbal aggressiveness is defined as attack on an individual's self-concept rather than attack to person's position on a topic of communication aiming at inflicting psychological pain to this person and often involves sat tacks to character or competence, physical appearance, racial features, as well as threats or teasing and cursing (Infante \& Rancer, 1996). Apparently, instructors' verbal aggressiveness decreases students' participativeness (Myers, Edwards, Wahl, \& Martin, 2007; Rocca, 2004), motivation and satisfaction or learning outcome (Bekiari, 2014; Bekiari \& Hasanagas, 2016 a, b; Bekiari, Kokaridas, \& Sakellariou, 2005; Bekiari, Koustelios, \& Sakellariou, 2000; Manoli \& Bekiari, 2015; Myers, 2002; Teven, 2007; Teven \& McCroskey, 1997; Thweatt \& McCroskey, 1998), affection in learning (Bekiari, 2012; Bekiari \& Manoli, 2016; Bekiari \& Tsaggopoulou, 2016; Myers et al., 2007; Schrodt, 2003; Wrench \& Punyanunt-Carter, 2005), attractiveness (Bekiari \& Petanidis, 2016; Syrmpas \& Bekiari, 2015), communicative competence (Bekiari \& Hasanagas, 2015; 2016 c; Bekiari \& Sakellariou, 2003; Buford, 2010; Rocca \& McCroskey, 1999), prosocial fairness (Hassandra, Bekiari, \& Sakellariou, 2007), Machiavellianism (Bekiari, 2016, 2017), intrinsic discipline (Bekiari, Kokaridas, \& Sakellariou, 2006; Bekiari \& Pylarinou, 2017; Bekiari \& Tsiana, 2016), bullying (Bekiari, Pachi, \& Hasanagas, 2017) and climate in class (Bekiari \& Syrmpas, 2015; Myers \& Rocca, 2000). In physical education, instructors' verbal aggressiveness is perceived as less favorable for the students and restricts sportsmanship (Kassing \& Infante, 1999) and credibility (Mazer, Barnes, Grevious, \& Boger, 2013) and feel less motivated (Bekiari, Perkos, \& Gerodimos, 2015). Bekiari, Digelidis, \& Sakellariou (2006) suggested that students who participate in non-contact sports perceive their instructors as less verbally aggressive in comparison with students participating in high-contact sports. Furthermore, male volleyball players perceived somatic anxiety as higher and felt more affected by verbal aggression than female players (Bekiari, Patsiaouras, Kokaridas, \& Sakellariou, 2006). There are also several studies including network analysis and typologies of verbal aggressive profiles (Bekiari \& Balla, 2017; Bekiari, Deliligka, \& Koustelios, 2016; Bekiari, Hasanagas, Theoharis, Kefalas, \& Vasilou, 2015; Bekiari, Nikolaidou, \& Hasanagas, 2017; Theoharis \& Bekiari, 2016 a, b).

Another instructor-dependent parameter having an impact on students' learning outcomes is the communicative style (Andersen, Norton, \& Nussbaum, 1981; Kearney \& McCroskey, 1980). Communicator style is supposed to contain an individual's ability to initiate, adapt or respond to the communication with others (Norton, 1978; Thomas, Richmond, \& McCroskey, 1994). Ten communicative attributes have been suggested: impression leaving, open, dramatic, 
contentious, precise, dominant, friendly, relaxed, animated and attentive (Norton, 1978). Socio-communicative style is composed of two main dimensions: responsiveness and assertiveness (McCroskey \& Richmond, 1996; Richmond \& Martin, 1998). Assertive communicators are able to begin, maintain, and interrupt discussions according to their interpersonal goals (Thomas, Richmond, \& McCroskey, 1994). These communicators act assertively speaking for themselves either to demand something or to externalize outbursts (Wheeless \& Lashbrook, 1987). On the other side, responsive communicators are more sensitive to others, listen to what others have to say, take the feelings of others seriously and recognize their needs (McCroskey \& Richmond, 1996). A responding communicator is characterized as a good listener, sensitive, compassionate, understanding, friendly, warm, honest and interesting. These properties are generally considered to characterize female subjects (McCroskey \& Richmond, 1996; Porter, Wrench, \& Hoskinson, 2007). Moreover, assertive individuals are considered to be extrovert and powerful whereas responsive individuals are regarded as trustworthy, sensitive, understanding and sociable (Kearney, 1984; Lamke, Sollie, Durbin, \& Fitzpatrick, 1994; Snavely, 1981). They also are considered to contribute to students' learning and satisfaction (Aylor \& Oppliger, 2003; Wanzer \& Frymier, 1999). However, independently of any communication style, unfulfilled expectations always exist and there irreconcilable students who steadily demand their fulfilment in any possible way, even through Machiavellian tactics.

A Machiavellian person is expected to be capable of influencing other people and control them, being motivated by self-interest (Walter, Anderson, \& Martin, 2005). Machiavellian persons are ideologically neutral, avoiding emotional involvement in interpersonal relations, and commitments (Dahling, Whitaker, \& Levy, 2009; Mudrack \& Mason, 1995). It has been supported that there is a negative relation between Machiavellian personality and conscientiousness (Paulhus \& Williams 2002), as well as a positive relation with impatience and everesthisia (Aziz \& Vallejo, 2007). It has been shown that features of a non-genuine person seem to be indicators of Machiavellianism (Ashton, Lee, \& Son, 2000). Additionally, a relationship between moral judgments and Machiavellianism appears (Mudrack, Bloodgood, \& Turnley, 2012; Pan \& Sparks, 2012; Shafer \& Simmons, 2008). Dahling, et al. (2009) proposed four dimensions in Machiavellianism: distrust, desire for control, desire for status and amoral manipulation. Older studies have shown that Machiavellian individuals follow offensive and dishonest way to achieve goals, they manipulate others to perform better and convince them, without being convinced by others (Christie \& Geis, 1970; Zagenczyk, Restubog, Kiewitz, Kiazad, \& Tang, 2014). Moreover, they tend to violate rights of others for personal interest (Zagenczyk et al., 2014) and show deviant behavior.

\section{Innovation and Questions of Study}

It can reasonably be supposed that the concepts of socio-communicative style, verbal aggressiveness and Machiavellianism have extensively been explored. 
Nevertheless, Machiavellian students in physical education have not yet proved to be related with socio-communicative style and verbal aggressiveness of instructors, as perceived by students. This study aims at investigating relations among perceived socio-communicative style and verbal aggressiveness of instructor sand students' Machiavellian tactics in physical education. The academic added value of this research consists in understanding deeper causes and interplay among the examined variables resulting in an over-bridging typology. The practical added value lies in detecting just in time phenomena which should be confronted.

Specifically, the following questions are expected to be answered:

- Are there any differences noted between the genders regarding verbal aggressiveness, socio-communicative style and Machiavellian tactics?

- Is there a positive or negative relationship between instructors' verbal aggressiveness as perceived by students with socio-communicative style and students' self-reports of Machiavellian tactics in physical education classes?

- To what extent the perceived instructors' verbal aggressiveness could be a significant predictor of their socio-communicative style and the students' Machiavellian tactics?

- Can students' and instructors' typology regarding parameters of verbal aggressiveness, socio-communicative style perception and Machiavellian tactics be extracted?

\section{Method}

\subsection{Participants and Procedures}

The sample of the study consisted of 269 students (141 males, 128 females) aged 12 - 14 years old $(M=12.6, S D=0.65)$ from secondary public schools, Greece. All the participants were between the $1^{\text {st }}$ grade (149 students) and $2^{\text {nd }}$ grade (120 students) of public secondary school sand belonged to different socio-economic status. All students completed questionnaires referring to the instructors' verbal aggressiveness and socio-communicative style and students' Machiavellian tactics, during their physical education lessons. The completion of questionnaires lasted for 20 - 30 minutes approximately and flowed freely. The informants participated anonymously and voluntarily. In this way, it is supposed to obtain sincere answers. Best practice rules and research ethics were observed.

\subsection{Instruments}

Verbal aggressiveness. The Greek version (Bekiari \& Digelidis, 2015), which was used to assess physical education instructor verbal aggressiveness, relied on the theoretical framework and the Verbal Aggressiveness Questionnaire developed by Infante \& Wigley (1986). Preliminary examination (Bekiari \& Digelidis, 2015) supported the psychometric properties of the instrument. In particular, confirmatory factor analysis indicated satisfactory fit indices (CFI: 0.97, SRMR: 0.02), and internal consistency of the scale $(\alpha=0.96)$. The scale consisted of eight 
items (e.g., "the teacher insults students", "the teacher makes negative judgments of students' ability"). Participants were asked to respond on a 5-point Likert-type scale ranging from 1: Strongly disagree to 5 : Strongly agree.

Socio-communicative style. The socio-communicative style questionnaire (Richmond \& McCroskey, 1990) was used to assess perceived instructors' socio-communicative style. The scale consisted of 20 items and two factors: responsiveness (10 items, e.g. "the teacher behaves in a courteous manner during the course", "the teacher shows responsibility towards the needs of his students") and assertiveness (10 items, e.g. "the teacher acts as a leader during the course", "I think he has a strong personality"). Factor analysis has demonstrated the two-dimensional structure of the instrument and the internal consistency of the subscales has been supported (from 0.88 to 0.96 ). Participants were asked to respond on a 5 point Likert scale (from $1=$ never to $5=$ often).

Machiavellianism. The Machiavellian Personality Scale (Dahling, Whitaker, \& Levy, 2009), a 16-item version, included four subscales: amoral manipulation (5 items, e.g., "the teacher is willing to be unethical if he believes it will help him succeed"), desire for control ( 3 items, e.g., "the teacher enjoys having control over other people"), desire for status (3 items, e.g., "the teacher wants to be rich and powerful someday") and distrust of others (5 items, e.g., "the teacher believes that people are only motivated by personal gain"). Factor analysis has demonstrated the four-dimensional structure of the instrument and the internal consistency of the subscales has been supported (from 0.70 to 0.83 ). Participants were asked to respond to the items based on a 5-point Likert-type scale ranging from $1=$ strongly agree to $5=$ strongly disagree.

\subsection{Data Analysis}

Data analysis included the use of the Statistical Package for Social Sciences (SPSS). The t-test for independent samples was used in order to reveal statistical significant differences between genders of the students. The Pearson correlation coefficient was used to measure the correlation between the subscales of the questionnaires. Regression analysis was conducted in order to explore the extent to which the perceived instructors' verbal aggressiveness could be a significant predictor of their socio-communicative style and students' Machiavellian tactics. The level of statistical significance was set at .05. Finally, students' and instructors' typology regarding parameters of verbal aggressiveness, socio-communicative style and Machiavellian tactics will be formulated using principal component analysis.

\section{Results}

Statistically significant differences were observed in instructors' verbal aggressiveness $\left(t_{1265}=8.25, p<0.001\right)$, responsiveness $\left(t_{1265}=-4.07, p<0.001\right)$, assertiveness $\left(t_{1265}=5.50, p<0.001\right)$, amoral manipulation $\left(t_{1265}=3.26, p<0.05\right)$, desire for control $\left(t_{1265}=2.11, p<0.05\right)$, desire for status $\left(t_{1265}=4.46, p<0.001\right)$ 
and distrust of others $\left(t_{1265}=3.69, p<0.001\right)$ between the two genders of the students (Table 1).

A correlation analysis was conducted, the results of which are presented in Table 2. As it can be seen, there was a negative significant relationship between instructors' verbal aggressiveness and responsiveness $(r=-0.441)$ and a positive significant relationship between verbal aggressiveness and assertiveness $(r=$ 0.393), amoral manipulation ( $r=0.376)$, desire for control $(r=0.199)$, desire for status $(r=0.307)$ and distrust of others $(r=0.458)$. At the same time, Table 2 presents the Cronbach's alpha, mean scores and standard deviations of the variables.

Linear regression analyses were conducted to examine the extent to which instructors' socio-communicative style and students' Machiavellian tactics could be predicted from the ratings of instructors' verbal aggressiveness. The results indicated that perceived instruct or verbal aggressiveness could predict significant variance in socio-communicative style $\left(F_{(2266)}=47.37, p<0.001\right)$ with an $R_{2}$ of $26.3 \%$. Perceived verbal aggressiveness explained $10.82 \%$ of the variance in responsiveness $(\beta=-0.33, t=-6.24, p<0.001)$ and $6.81 \%$ of the variance in assertiveness $(\beta=0.31, t=4.95, p<0.001)$. Another linear regression analysis was conducted to predict student Machiavellian tactics based on teacher verbal aggressiveness. The results indicated that perceived instructor verbal aggressiveness could predict significant variance in Machiavellian tactics $\left(F_{(4264)}=24.52, p\right.$ $<0.001$ ) with an $R_{2}$ of $27.1 \%$. Verbal aggressiveness explained $4.75 \%$ of the variance in students' desire for status $(\beta=0.15, t=4.15, p<0.001)$ and $6.97 \%$ of the variance in students' distrust of others $(\beta=0.25, t=5.02, p<0.001)$. The results of the regression analyses are presented in Table 3 .

Table 1. Students' gender comparison.

\begin{tabular}{|c|c|c|c|c|c|c|c|}
\hline Variables & Gender & $\mathrm{N}$ & Mean & $\mathrm{SD}$ & $t$ & df & $p$ \\
\hline \multirow{2}{*}{ Verbal aggressiveness } & Males & 141 & 3.36 & 0.55 & \multirow{2}{*}{8.25} & \multirow{2}{*}{267} & \multirow{2}{*}{0.000} \\
\hline & Females & 128 & 2.75 & 0.64 & & & \\
\hline \multirow{2}{*}{ Responsiveness } & Males & 141 & 3.26 & 0.68 & \multirow{2}{*}{-4.07} & \multirow{2}{*}{267} & \multirow{2}{*}{0.000} \\
\hline & Females & 128 & 3.60 & 0.67 & & & \\
\hline \multirow[t]{2}{*}{ Assertiveness } & Males & 141 & 3.28 & 0.56 & \multirow[t]{2}{*}{5.50} & \multirow[t]{2}{*}{267} & \multirow[t]{2}{*}{0.000} \\
\hline & Females & 128 & 2.90 & 0.57 & & & \\
\hline \multirow{2}{*}{ Amoral manipulation } & Males & 141 & 2.64 & 0.70 & \multirow{2}{*}{3.26} & \multirow{2}{*}{267} & \multirow{2}{*}{0.001} \\
\hline & Females & 128 & 2.35 & 0.76 & & & \\
\hline \multirow[t]{2}{*}{ Desire for control } & Males & 141 & 1.99 & 0.82 & \multirow[t]{2}{*}{2.11} & \multirow[t]{2}{*}{267} & \multirow[t]{2}{*}{0.036} \\
\hline & Females & 128 & 1.80 & 0.69 & & & \\
\hline \multirow[t]{2}{*}{ Desire for status } & Males & 141 & 3.77 & 0.99 & \multirow[t]{2}{*}{4.46} & \multirow[t]{2}{*}{267} & \multirow[t]{2}{*}{0.000} \\
\hline & Females & 128 & 3.22 & 1.05 & & & \\
\hline \multirow{2}{*}{ Distrust of others } & Males & 141 & 3.23 & 0.81 & \multirow{2}{*}{3.69} & \multirow{2}{*}{267} & \multirow{2}{*}{0.000} \\
\hline & Females & 128 & 2.83 & 0.99 & & & \\
\hline
\end{tabular}


Table 2. Reliabilities, means, standard deviations and pearson correlations among variables.

\begin{tabular}{|c|c|c|c|c|c|c|c|c|c|}
\hline & $\alpha$ & $\mathrm{M}(S D)$ & 1 & 2 & 3 & 4 & 5 & 6 & 7 \\
\hline 1) Verbal aggressiveness & 0.71 & $2.89(0.67)$ & - & & & & & & \\
\hline 2) Responsiveness & 0.79 & $3.42(0.70)$ & $-0.44^{* *}$ & - & & & & & \\
\hline 3) Assertiveness & 0.70 & $3.08(0.59)$ & $0.39^{* *}$ & $-0.33^{* \star}$ & - & & & & \\
\hline 4) Amoral manipulation & 0.68 & $2.49(0.74)$ & $0.38^{* *}$ & $-0.47^{* *}$ & $0.32^{* *}$ & - & & & \\
\hline 5. Desire for control & 0.69 & $1.90(0.76)$ & $0.20^{\star *}$ & $-0.32^{\star \star}$ & 0.07 & $0.50^{* *}$ & - & & \\
\hline 6) Desire for status & 0.73 & $3.51(0.98)$ & $0.31^{* *}$ & $-0.20^{* *}$ & $0.28^{\star *}$ & $0.21^{\star *}$ & -0.11 & - & \\
\hline 7) Distrust of others & 0.82 & $3.04(0.92)$ & $0.46^{* *}$ & $-0.39^{* *}$ & $0.31^{* *}$ & $0.64^{* *}$ & $0.26^{* *}$ & $0.22^{* *}$ & - \\
\hline
\end{tabular}

Table 3. Regression analysis results according to verbal aggressiveness.

\begin{tabular}{cccccc}
\hline & $\mathrm{B}$ & $95 \% \mathrm{CI} B$ & $\mathrm{SE}$ & $\mathrm{B}$ & $\mathrm{T}$ \\
\hline Responsiveness & -0.35 & $-0.23,-0.44$ & 0.05 & -0.33 & $-6.24^{* *}$ \\
Assertiveness & 0.28 & $0.19,0.43$ & 0.06 & 0.31 & $4.95^{* *}$ \\
Desire for status & 0.23 & $0.08,0.22$ & 0.04 & 0.15 & $4.15^{* *}$ \\
Distrust of others & 0.35 & $0.15,0.35$ & 0.05 & 0.25 & $5.02^{* *}$ \\
\hline${ }^{*} p<0.05,{ }^{* *} p<0.001$. & & & & &
\end{tabular}

In the Table 4, three behavioral types are revealed: 1) the unrestraint, 2) the responsive, and 3) the distrustful. The first type can be regarded as dominant, the second one as sociable and the third one as just cautious or weak.

\section{Discussion}

Goal of this study is fourfold: 1) to investigate differences between genders regarding verbal aggressiveness, socio-communicative style and Machiavellian tactics, 2) to explore the relationship between perceived physical education instructors' verbal aggressiveness and socio-communicative style as perceived by students and students' Machiavellianism, 3) to investigate the influence of instructor verbal aggressiveness on their socio-communicative style and student Machiavellian tactics and 4) to propose students' and instructors' typology which will be the final over-bridging of verbal aggressiveness and Machiavellianism through communication style. According the results, statistically significant differences were observed in all variables between the genders of the students. Verbal aggressiveness was positively related to assertiveness, amoral manipulation, desire for control, desire for status, distrust of others and was negatively related to responsiveness. Perceived instructors' verbal aggressiveness could significantly predict the variables of responsiveness, assertiveness, desire for status and distrust of others. Three behavioral types are revealed: 1) the unrestraint, 2) the responsive, and 3) the distrustful. 
Table 4. Typology of behavioral patterns.

\begin{tabular}{|c|c|c|c|c|}
\hline & & The "unrestraint" & The "responsive" & The "distrustful" \\
\hline \multirow{4}{*}{$\begin{array}{c}\text { Verbal } \\
\text { aggressiveness }\end{array}$} & Rudeness & 0.790 & -0.026 & -0.224 \\
\hline & Degrading students & 0.822 & 0.023 & -0.215 \\
\hline & $\begin{array}{l}\text { Causing bad feeling to } \\
\text { students }\end{array}$ & 0.786 & 0.074 & -0.170 \\
\hline & Mockery & 0.805 & -0.004 & -0.202 \\
\hline \multirow{4}{*}{ Responsiveness } & Polite behavior & -0.087 & 0.674 & 0.150 \\
\hline & Compassion & -0.145 & 0.616 & 0.011 \\
\hline & Honest behavior & -0.093 & 0.613 & -0.102 \\
\hline & Willingness to help & -0.032 & 0.712 & -0.083 \\
\hline \multirow{3}{*}{ Assertiveness } & Acting as a leader & 0.797 & 0.060 & -0.297 \\
\hline & Becoming aggressive & 0.803 & 0.064 & -0.260 \\
\hline & Imposing his views & 0.817 & 0.047 & -0.261 \\
\hline \multirow{3}{*}{$\begin{array}{c}\text { Distrust of } \\
\text { others }\end{array}$} & Back stabbing & 0.782 & 0.085 & 0.531 \\
\hline & Exploiting weaknesses & 0.777 & 0.072 & 0.557 \\
\hline & $\begin{array}{l}\text { Exploiting the situation } \\
\text { against others }\end{array}$ & 0.733 & 0.080 & 0.611 \\
\hline
\end{tabular}

Extraction method: Principal component analysis, 3 components extracted.

In the present study, male students seem to regard their instructors as more verbally aggressive than female ones. This is confirmed by previous research which has supported that educators are more verbally aggressive against boys than against girls (Bekiari, 2014; Bekiari \& Hasanagas, 2015). Consequently, male students perceive their instructors as more verbally aggressive, assertive and autocratic than female ones. This seems to cause them more desire for amoral manipulation, desire for control, desire for status and distrust. These results are also confirmed by findings of other studies where instructors have proved to be more aggressive towards male students because of their disobedience and indiscipline during the lesson (Bekiari \& Petanidis, 2016). So it is likely that the aggressiveness of the educators is the main reason why male students present more intensive Machiavellian tactics. However, the verbal aggressive attitude is obviously dissuasive for all trainees, regardless of gender (Gorham \& Christophel, 1992).

The results of this study showed a positive relation of verbal aggressiveness by assertiveness, desire for control and status, amoral manipulation, distrust and a negative relation with responsiveness. This concurs with the tenor of previous research revealing that teenagers with Machiavellian behavior show weak communication within family and less satisfaction with family life (Láng \& Birkás, 2015; Olson, 2000; Ryumshina, 2013). Other analyses have shown that the appearance of Machiavellianism is related with the instructors' behavior (Martin, Myers, \& Mottet, 2006), since the verbal aggressiveness seems to indicate trai- 
nees' Machiavellian (Bekiari, 2016), as Machiavellians use dishonest and offensive means (Christie \& Geis, 1970) and tend to practice divergent behaviors (Zagenczyk et al., 2014), cheating and dominating (Talwar \& Lee, 2011), as Machiavellianism can be seen as a reaction to aggressive behavior by educators (McDonald, Donnellan, \& Navarrete, 2012). Finally, results are in accordance with other studies supporting that verbal aggressiveness is negatively related with students' intrinsic motivation and instructors' responsiveness (Bekiari, 2012, 2014; Bekiari, Perkos, \& Gerodimos, 2015; Bekiari \& Syrmpas, 2015; Hamilton \& Hample, 2011) and positively related with assertiveness (Bekiari \& Pylarinou, 2017). Additionally, it is revealed that instructors' personality plays a determinant role in students' behavior, emotions, tactics and attitudes (Horn, 2002; Infante \& Rancer, 1996; Rancer \& Avtgis, 2014). Moreover, perceived verbal aggressiveness proved to be the most important predictor of students' Machiavellianism, which is in accordance with previous findings showing that instructors' verbal aggressiveness is positively related with students' Machiavellian tactics, such as amoral manipulation, desire for status, desire for control, distrust and antisocial fair play behaviors, such as gamesmanship and cheating (Bekiari, 2017; Hassandra, Bekiari, \& Sakellariou, 2007). According to Láng \& Lénárd (2015), the negative climate at home and loneliness seem to be negatively correlated with Machiavellianism while punishment seems also to foster Machiavellianism. Thus, Machiavellianism can also be regarded as a reaction to inconveniences in childhood (McDonald, Donnellan, \& Navarrete, 2012). This seems to be supported in case of corporal punishment (Waller, Gardner, Hyde, Shaw, Dishion, \& Wilson, 2012). Machiavellianism in childhood can also be a reaction to authoritarianism (Talwar \& Lee, 2011) while in adults it may be correlated with hostile attitudes and emotions (Locke \& Christiensen, 2007) as well as with verbal aggressiveness (Andreou, 2004; Bereczkei, 2015; Corzine \& Hozier, 2005). On the contrary, Cranmer \& Martin (2015) argue that morality is negatively correlated with Machiavellianism.

Moreover, in this study, three behavioral types are revealed: 1) the unrestraint, 2) the responsive, and 3) the distrustful. The first type can be regarded as dominant, the second one as sociable and the third one as just cautious or weak. The unrestraint type is someone who freely externalizes his verbal aggressiveness, offending self-perception of others. Simultaneously, he remains assertive reducing any scope of disputing action. Additionally, he appears to be invulnerable toward any emotion- or trust-based manipulation, as he is both amoral and distrustful. In other words, a combination of aggressiveness and defensiveness is the behavioral profile of the unrestraint type. It could be regarded as a type aiming at absolute dominance. The responsive type just consists of dimensions of responsiveness. This type points out the conceptual purity and independence of the responsiveness. In contrast to the unrestraint type, who consists of various behavioral dimensions, the responsive type is exclusively confined on the responsiveness to others, without combining this with any dimension of verbal aggressiveness, assertiveness, amorality or distrustfulness. Thus, responsiveness 
seems to fully independent of any dominance pattern. It rather seems to be an expression of pure communicativeness and sociability. Finally, the distrustful type appears to be the plainest one as it consists in only one dimension of distrustfulness. Thus, it rather seems to express a slightly defensive and cautious or even coward and weak type than a type susceptible to dominance or sociability, as the restraint and responsive type. Such typologies have also been suggested in previous researches (Bekiari, Deliligka, \& Hasanagas, 2017; Bekiari \& Pachi, 2017; Bekiari \& Spyropoulou, 2016; Hasanagas \& Bekiari, 2015, 2017; Hasanagas, Bekiari, \& Vasilos, 2017; Theoharis \& Bekiari, 2017 a, b; Theoharis, Bekiari, \& Koustelios, 2017).

A normative suggestion on the basis of the particular empirical findings is that physical education instructors should avoid adopting verbal aggressive behavior, as Machiavellianism is enhanced by aggressiveness, superficial obedience, unfairness and antisocial fair play behaviors. Instead, instructors should adopt a responsive communicator style, which favors the supportive classroom climate, self-confidence and motivation. Responsiveness is considered to enhance flexibility, cohesion and moral development. Furthermore, responsiveness refers to the degree in which communication reflects sensitivity to students and their feelings, including cases of helpfulness, sympathy, compassion, sincerity, sensitivity, gentleness, warm behavior, friendliness and tenderness (Allen, Long, O'Mara, \& Judd, 2008). In addition, instructors who use the characteristics of friendliness, diligence and comfort of the communication style are considered to be more lovable than students (Potter \& Emanuel, 1990). It can thus be expected that responsiveness acts as an over-bridging between verbal aggressive instructors and Machiavellian students.

In sum, when instructors adopt a verbally aggressive and assertive communication, it seems that they decrease the probability to appear amoral manipulation, desire for status, desire for control and distrust during physical education lessons. The results of the study highlight the demand for improvement in physical education instructor in order to respond to a challenging and constantly changing field. This study not only contributes to our understanding of factors associated with students' Machiavellian tactics but also corroborates the results produced by previous studies. Moreover, as the communication is a vital function of student learning (Frymier \& Houser, 1997), future research can be conducted on the student-instructor interaction, especially focusing on the instructors' communicative attributes (i.e. argumentativeness, verbal aggressiveness, communicative style) associated with students' Machiavellianism. The restricted sample is a limitation of this research and thus, it constitutes a challenge for future research. Simultaneously, more parameters can be analyzed in future.

\section{Conclusion}

Male students perceive their instructors as more verbally aggressive, assertive and autocratic than female ones. This seems to cause them more desire for 
amoral manipulation, desire for control, desire for status and distrust of others. When instructors adopt a verbally aggressive and assertive communication, it seems that they decrease the probability to appear amoral manipulation, desire for status, desire for control and distrust during physical education lessons. Perceived verbal aggressiveness proved to be the most important predictor of responsiveness, assertiveness, desire for status and distrust. Three behavioral types are revealed: 1) the unrestraint (a combination of aggressiveness and defensiveness), 2) the responsive (an expression of pure communicativeness and sociability), and 3) the distrustful (just cautious or weak type than a type susceptible to dominance or sociability). Instructors should adopt a responsive communicator style, which favors the supportive classroom climate, self-confidence, motivation, as responsiveness is considered to enhance flexibility, cohesion and moral development. It can thus be expected that responsiveness acts as an over-bridging between verbal aggressive instructors and Machiavellian students.

\section{Conflicts of Interest}

There are no known conflicts of interest associated with this publication.

\section{References}

Allen, J. L., Long, K. M., O'mara, J., \& Judd, B. B. (2008). Students' Predispositions and Orientations toward Communication and Perceptions of Instructor Reciprocity and Learning. Communication Education, 57, 20-40. https://doi.org/10.1080/03634520701670908

Andersen, J. F., Norton, R. W., \& Nussbaum, J. F. (1981). Three Investigations Exploring Relationships between Perceived Teacher Communication Behaviors and Student Learning. Communication Education, 30, 377-392. https://doi.org/10.1080/03634528109378493

Andreou, E. (2004). Bully/Victim Problems and Their Association with Machiavellianism and Self-Efficacy in Greek Primary School Children. British Journal of Educational Psychology, 74, 297-309. https://doi.org/10.1348/000709904773839897

Ashton, M. C., Lee, K., \& Son, C. (2000). Honesty as the Sixth Factor of Personality: Correlations with Machiavellianism, Primary Psychopathy, and Social Adroitness. European Journal of Personality, 14, 359-368. https://doi.org/10.1002/1099-0984(200007/08)14:4<359::AID-PER382>3.0.CO;2-Y

Aylor, B., \& Oppliger, P. (2003). Out-of-Class Communication and Student Perceptions of Instructor Humor Orientation and Socio-Communicative Style. Communication Education, 52, 122-134. https://doi.org/10.1080/03634520302469

Aziz, A., \& Vallejo, D. (2007). An Exploratory Study of the Facets of Type A Personality and Scores on the Machiavellian Behavior (MACH-B) Scale. Psychological Reports, 101, 555-560. https://doi.org/10.2466/pr0.101.2.555-560

Bekiari, A. (2012). Perceptions of Instructors' Verbal Aggressiveness and Physical Education Students' Affective Learning. Perceptual and Motor Skills, 115, 325-335. https://doi.org/10.2466/06.11.16.PMS.115.4.325-335

Bekiari, A. (2014). Verbal Aggressiveness and Leadership Style of Sports Instructors and Their Relationship with Athletes' Intrinsic Motivation. Creative Education, 5, 114-121. https://doi.org/10.4236/ce.2014.52018 
Bekiari, A. (2016). Insights into Instructors' Verbal Aggressiveness and Students' Machiavellianism through Leadership Style and Motivational Climate. European Scientific Journal, 12, 90-110. https://doi.org/10.19044/esj.2016.v12n25p90

Bekiari, A. (2017). Exploring Relations between Instructors' Verbal Aggressiveness and Argumentativeness and Students' Fair Play Behaviours and Machiavellianism. International Journal of Physical Education, 54, 26-39.

Bekiari, A., \& Balla, K. (2017). Instructors and Students Relations: Argumentativeness, Leadership and Goal Orientations. Open Journal of Social Sciences, 5, 128-143. https://doi.org/10.4236/jss.2017.57009

Bekiari, A., \& Digelidis, N. (2015). Measuring Verbal Aggressiveness in Sport and Education. International Journal of Physical Education, 52, 12-21.

Bekiari, A., \& Hasanagas, N. (2015). Verbal Aggressiveness Exploration through Complete Social Network Analysis: Using Physical Education Students' Class as an Illustration. International Journal of Social Science Studies, 3, 30-49. https://doi.org/10.11114/ijsss.v3i3.729

Bekiari, A., \& Hasanagas, N. (2016a). Sociological Insights in the Education System: "Unlocking" the Power Relations. Thessaloniki: AfoiKyriakidi Editions S.A.

Bekiari, A., \& Hasanagas, N. (2016b). "Educating” in Physical Education. Theoretical Approaches and Practical Inquiries. Thessaloniki: AfoiKyriakidi Editions S.A.

Bekiari, A., \& Hasanagas, N. (2016c). Suggesting Indicators of Superficiality and Purity in Verbal Aggressiveness. An Application in Adult Education Class Networks of Prisoners. Open Journal of Social Sciences, 4, 279-292. https://doi.org/10.4236/jss.2016.43035

Bekiari, A., \& Manoli, P. (2016). EFL Teacher Verbal Aggressiveness and Argumentativeness and Student Socio-Affective Strategy Use and Affective Learning: Exploring Possible Associations. Journal of Teacher Education and Educators, 5, 154-171.

Bekiari, A., \& Pachi, V. (2017). Insights into Bullying and Verbal Aggressiveness through Social Network Analysis. Journal of Computer and Communications, 5, 79-101. https://doi.org/10.4236/jcc.2017.59006

Bekiari, A., \& Petanidis, D. (2016). Exploring Teachers' Verbal Aggressiveness through Interpersonal Attraction and Students' Intrinsic Motivation. Open Journal of Social Sciences, 4, 72-85. https://doi.org/10.4236/jss.2016.412007

Bekiari, A., \& Pylarinou, M. (2017). Instructor Argumentativeness and Socio-Communicative Style and Student Discipline: Using Physical Education Students' Class as an Illustration. Open Journal of Social Sciences, 5, 122-136. https://doi.org/10.4236/jss.2017.53011

Bekiari, A., \& Sakellariou, K. (2003). Perceived Instructor Verbal Aggressiveness and Student State Learning in Physical Education. Italian Journal of Sport Sciences, 1, 251256.

Bekiari, A., \& Spyropoulou, S. (2016). Exploration of Verbal Aggressiveness and Interpersonal Attraction through Social Network Analysis: Using University Physical Education Class as an Illustration. Open Journal of Social Sciences, 4, 145-155. https://doi.org/10.4236/jss.2016.46016

Bekiari, A., \& Syrmpas, I. (2015). Coaches' Verbal Aggressiveness and Motivational Climate as Predictors of Athletes' Satisfaction. British Journal of Education, Society \& Behavioural Science, 9, 318-329. https://doi.org/10.9734/BJESBS/2015/17757

Bekiari, A., \& Tsaggopoulou, T. (2016). Verbal Aggressiveness and Affective Learning in Physical Education. Advances in Physical Education, 6, 406-418.

https://doi.org/10.4236/ape.2016.64041 
Bekiari, A., \& Tsiana, I. (2016). Exploring Instructors' Verbal Aggressiveness and Students' Personal Orientations and Reasons of Discipline in Physical Education Class. Advances in Physical Education, 6, 158-168. https://doi.org/10.4236/ape.2016.63018

Bekiari, A., Deliligka, S., \& Hasanagas, N. (2017). Analysing Networks of Verbal Aggressiveness and Motivation. Psychology, 8, 495-515. https://doi.org/10.4236/psych.2017.83031

Bekiari, A., Deliligka, S., \& Koustelios, A. (2016). Examining Relations of Aggressive Communication in Social Networks. Social Networking, 6, 38-52. https://doi.org/10.4236/sn.2017.61003

Bekiari, A., Digelidis, N., \& Sakellariou, K. (2006). Perceived Verbal Aggressiveness of Coaches in Volleyball and Basketball: A Preliminary Study. Psychological Reports, 103, 526-530.

Bekiari, A., Kokaridas, D., \& Sakellariou, K. (2005). Verbal Aggressiveness of Physical Education Teachers and Students' Self-Reports of Behaviour. Psychological Reports, 96, 493-498. https://doi.org/10.2466/pr0.96.2.493-498

Bekiari, A., Kokaridas, D., \& Sakellariou, K. (2006). Associations of Students' Self-Reports of Their Teacher's Verbal Aggression, Intrinsic Motivation, and Perceptions of Reasons for Discipline in Greek Physical Education Classes. Psychological Reports, 98, 451-461. https://doi.org/10.2466/pr0.98.2.451-461

Bekiari, A., Koustelios, A., \& Sakellariou, K. (2000). Instructors' Verbal Aggressiveness from Universities in Greece. Studi e Ricerche, 5, 225-232.

Bekiari, A., Nikolaidou, Z., \& Hasanagas, N. (2017). Typology of Motivation and Aggression on the Basis of Social Network Variables: Examples of Complementary and Nested Behavioral Types through Conventional Statistics. Social Networking, 6, 135-147. https://doi.org/10.4236/sn.2017.62008

Bekiari, A., Pachi, V., \& Hasanagas, N. (2017). Investigating Bullying Determinants and Typologies with Social Network Analysis. Journal of Computer and Communications, 5, 11-27. https://doi.org/10.4236/jcc.2017.57002

Bekiari, A., Patsiaouras, A., Kokaridas, D., \& Sakellariou, K. (2006). Verbal Aggressiveness and State Anxiety of Volleyball Players and Coaches. Psychological Reports, 99, 630-634. https://doi.org/10.2466/pr0.99.2.630-634

Bekiari, A., Perkos, S., \& Gerodimos, V. (2015). Verbal Aggression in Basketball: Perceived Coach Use and Athlete Intrinsic and Extrinsic Motivation. Journal of Physical Education and Sport, 15, 96-102.

Bekiari, A., Hasanagas, N., Theoharis, D., Kefalas, I., \& Vasilou, A. (2015). The Role of Mathematical Object and the Educational Environment to Students' Interpersonal Relationships: An Application of Full Social Network Analysis. In Hellenic Mathematical Society (Ed.), Proceedings of the 32nd Congress Greek Mathematical Society (with International Participation) (pp. 799-812). Athens: Hellenic Mathematical Society.

Bereczkei, T. (2015). The Manipulative Skill: Cognitive Devices and Their Neural Correlates Underlying Machiavellian's Decision Making. Brain and Cognition, 99, 24-31. https://doi.org/10.1016/j.bandc.2015.06.007

Buford, K. (2010). Native American Son: The Life and Sporting Legend of Jim Thorpe. New York: Knopf.

Christie, R., \& Geis, F. L. (1970). Machiavellianism. New York: Academic Press.

Corzine, J. B., \& HozierJr, G. C. (2005). Exploratory Study of Machiavellianism and Bases of Social Power in Bankers. Psychological Reports, 97, 356-362.

https://doi.org/10.2466/pr0.97.2.356-362 
Cranmer, G. A., \& Martin, M. M. (2015). An Examination of Aggression and Adaption Traits with Moral Foundation. Communication Research Reports, 32, 360-366. https://doi.org/10.1080/08824096.2015.1089848

Dahling, J. J., Whitaker, B. G., \& Levy, P. E. (2009). The Development and Validation of a New Machiavellianism Scale. Journal of Management, 35, 219-257. https://doi.org/10.1177/0149206308318618

Frymier, A. B., \& Houser, M. L. (1997). The Role of Communication in Learning: Does Talking Make You Learn More. In National Communication Association (Ed.), Proceedings of Annual Meeting of the National Communication Association. Chicago, IL: National Communication Association.

Gorham, J., \& Christophel, D. M. (1992). Students' Perceptions of Teacher Behaviors as Motivating and Demotivating Factors in College Classes. Communication Quarterly, 40, 239-252. https://doi.org/10.1080/01463379209369839

Hamilton, M., \& Hample, D. (2011). Testing Hierarchical Models of Argumentativeness and Verbal Aggressiveness. Communication Methods and Measures, 5, 250-273. https://doi.org/10.1080/19312458.2011.596991

Hasanagas, N., \& Bekiari, A. (2015). Depicting Determinants and Effects of Intimacy and Verbal Aggressiveness Target through Social Network Analysis. Sociology Mind, 5, 162-175. https://doi.org/10.4236/sm.2015.53015

Hasanagas, N., \& Bekiari, A. (2017). An Exploration of the Relation between Hunting and Aggressiveness: Using Inmates Networks at Prison Secondary School as an Illustration. Social Networking, 6, 19-37. https://doi.org/10.4236/sn.2017.61002

Hasanagas, N., Bekiari, A., \& Vasilos, P. (2017). Friendliness to Animals and Verbal Aggressiveness to People: Using Prison Inmates Education Networks as an Illustration. Social Networking, 6, 224-238. https://doi.org/10.4236/sn.2017.63015

Hassandra, M., Bekiari, A., \& Sakellariou, K. (2007). Physical Education Teacher's Verbal Aggression and Student's Fair Play Behaviors. The Physical Educator, 64, 94-101.

Horn, T. S. (2002). Coaching Effectiveness in Sport Domain: Advances in Sport Psychology. Journal of Psychology, 7, 134-149.

Infante, D. A., \& Rancer, A. S. (1996). Argumentativeness and Verbal Aggressiveness: A Review of Recent Theory and Research. Annals of the International Communication Association, 19, 319-352. https://doi.org/10.1080/23808985.1996.11678934

Infante, D. A., \& Wigley, I. C. J. (1986). Verbal Aggressiveness: An Interpersonal Model and Measure. Communications Monographs, 53, 61-69. https://doi.org/10.1080/03637758609376126

Kassing, J. W., \& Infante, D. A. (1999). Aggressive Communication in the Coach-Athlete Relationship. Communication Research Reports, 16, 110-120. https://doi.org/10.1080/08824099909388708

Kearney, P. (1984). Perceptual Discrepancies in Teacher Communication Style. Communication Education, 13, 95-105.

Kearney, P., \& McCroskey, J. C. (1980). Relationships among Teacher Communication Style, Trait and State Communication Apprehension and Teacher Effectiveness. Communication Yearbook, 4, 533-551.

Lamke, L. K., Sollie, D. L., Durbin, R. G., \& Fitzpatrick, J. A. (1994). Masculinity, Femininity and Relationship Satisfaction: The Mediating Role of Interpersonal Competence. Journal of Social and Personal Relationships, 11, 535-554.

https://doi.org/10.1177/0265407594114003 
Láng, A., \& Birkás, B. (2015). Machiavellianism and Parental Attachment in Adolescence: Effect of the Relationship with Same-Sex Parents. SAGE Open, 5, 1-7. https://doi.org/10.1177/2158244015571639

Láng, A., \& Lénárd, K. (2015). The Relation between Memories of Childhood Psychological Maltreatment and Machiavellianism. Personality and Individual Differences, 77, 81-85. https://doi.org/10.1016/j.paid.2014.12.054

Locke, K. D., \& Christensen, L. (2007). Re-Construing the Relational-Interdependent Self-Construal and Its Relationship with Self-Consistency. Journal of Research in Personality, 41, 389-402. https://doi.org/10.1016/j.jrp.2006.04.005

Manoli, P., \& Bekiari, A. (2015). EFL Teachers' Verbal Aggressiveness and Students' Intrinsic Motivation and Social-Affective Strategy Use: Investigating Possible Relations. Advances in Research, 5, 1-13. https://doi.org/10.9734/AIR/2015/19692

Martin, M. M., Myers, S. A., \& Mottet, T. P. (2006). Students' Machiavellianism and Motives for Communicating with Instructors. Psychological Reports, 98, 861-864. https://doi.org/10.2466/pr0.98.3.861-864

Mazer, J. P., Barnes, K., Grevious, A., \& Boger, C. (2013). Coach Verbal Aggression: A Case Study Examining Effects on Athlete Motivation and Perceptions of Coach Credibility. International Journal of Sport Communication, 6, 203-213. https://doi.org/10.1123/ijsc.6.2.203

McCroskey, J. C., \& Richmond, V. P. (1996). Human Communication Theory and Research: Traditions and Models. In D. W. Stacks, \& M. B. Salwen (Eds.), An Integrated Approach to Communication Theory and Research (pp. 233-242). New York: Routledge.

McDonald, M. M., Donnellan, M. B., \& Navarrete, C. D. (2012). A Life History Approach to Understanding the Dark Triad. Personality and Individual Differences, 52, 601-605. https://doi.org/10.1016/j.paid.2011.12.003

Mudrack, P. E., \& Mason, E. S. (1995). Extending the Machiavellianism Construct: A Brief Measure and Some Unexplored Relationships. Journal of Social Behavior and Personality, 10, 187.

Mudrack, P. E., Bloodgood, J. M., \& Turnley, W. H. (2012). Some Ethical Implications of Individual Competitiveness. Journal of Business Ethics, 108, 347-359.

https://doi.org/10.1007/s10551-011-1094-4

Myers, S. A. (2002). Perceived Aggressive Instructor Communication and Student State Motivation, Learning, and Satisfaction. Communication Reports, 15, 113-121. https://doi.org/10.1080/08934210209367758

Myers, S. A., \& Rocca, K. A. (2000). The Relationship between Perceived Instructor Communicator Style, Argumentativeness, and Verbal Aggressiveness. Communication Research Reports, 17, 1-12. https://doi.org/10.1080/08824090009388745

Myers, S. A., Edwards, C., Wahl, S. T., \& Martin, M. M. (2007). The Relationship between Perceived Instructor Aggressive Communication and College Student Involvement. Communication Education, 56, 495-508. https://doi.org/10.1080/03634520701466398

Norton, R. W. (1978). Foundation of a Communicator Style Construct. Human Communication Research, 4, 99-112. https://doi.org/10.1111/j.1468-2958.1978.tb00600.x

Olson, M. (2000). Power and Prosperity: Outgrowing Communist and Capitalist Dictatorships: Outgrowing Communist and Capitalist Dictatorships. New York: Basic Books. 
Pan, Y., \& Sparks, J. R. (2012). Predictors, Consequence, and Measurement of Ethical Judgments: Review and Meta-Analysis. Journal of Business Research, 65, 84-91. https://doi.org/10.1016/j.jbusres.2011.02.002

Paulhus, D. L., \& Williams, K. M. (2002). The Dark Triad of Personality: Narcissism, Machiavellianism, and Psychopathy. Journal of Research in Personality, 36, 556-563. https://doi.org/10.1016/S0092-6566(02)00505-6

Piko, B. F., \& Keresztes, N. (2006). Physical Activity, Psychosocial Health and Life Goals among Youth. Journal of Community Health, 31, 136.

https://doi.org/10.1007/s10900-005-9004-2

Porter, H., Wrench, J. S., \& Hoskinson, C. (2007). Superior/Subordinate Relationships: Understanding the Effects of a Supervisor's Temperament on Employee Motivation, Job Satisfaction, Perception's of a Superior's Socio-Communicative Style, and Superior's Level of Approachability. Communication Quarterly, 55, 129-153. https://doi.org/10.1080/01463370600998517

Potter, W. J., \& Emanuel, R. (1990). Students' Preferences for Communication Styles and Their Relationship to Achievement. Communication Education, 39, 234-249. https://doi.org/10.1080/03634529009378805

Rancer, A. S., \& Avtgis, T. A. (2014). Argumentative and Aggressive Communication: Theory, Research, and Application (2nd ed.). New York: Peter Lang.

Richmond, V. P., \& Martin, M. M. (1998). Socio-Communicative Style. In J. C. Mccroskey (Ed.), Communication and Personality: Trait Perspectives (pp. 133-148). Baton Rouge, LA: Hampton Public Relations.

Richmond, V. P., \& McCroskey, J. C. (1990). Reliability and Separation of Factors on the Assertiveness-Responsiveness Measure. Psychological Reports, 67, 449-450.

https://doi.org/10.2466/pr0.1990.67.2.449

Rocca, K. A. (2004). College student Attendance: Impact of Instructor Immediacy and Verbal Aggression: Brief Report. Communication Education, 53, 185-195. https://doi.org/10.1080/03634520410001682447

Rocca, K. A., \& McCroskey, J. C. (1999). The Interrelationship of Student Ratings of Instructors' Immediacy, Verbal Aggressiveness, Homophily, and Interpersonal Attraction. Communication Education, 48, 308-316. https://doi.org/10.1080/03634529909379181

Ryumshina, L. I. (2013). Family Influence on Formation of Children's Manipulative Attitudes. International Journal of Cognitive Research in Science, Engineering and Education (IJCRSEE), 1, 14-18.

Schrodt, P. (2003). Students' Appraisals of Instructors as a Function of Students' Perceptions of Instructors' Aggressive Communication. Communication Education, 52, 106121. https://doi.org/10.1080/03634520302468

Shafer, W. E., \& Simmons, R. S. (2008). Social Responsibility, Machiavellianism and Tax Avoidance: A Study of Hong Kong Tax Professionals. Accounting, Auditing \& Accountability Journal, 21, 695-720. https://doi.org/10.1108/09513570810872978

Snavely, W. B. (1981). The Impact of Social Style upon Person Perception in Primary Relationships. Communication Quarterly, 29, 132-143.

https://doi.org/10.1080/01463378109369398

Syrmpas, I., \& Bekiari, A. (2015). The Relationship between Perceived Physical Education Teacher's Verbal Aggressiveness and Argumentativeness with Students' Interpersonal Attraction. Inquiries in Sport \& Physical Education, 13, 21-32. 
Talwar, V., \& Lee, K. (2011). A Punitive Environment Fosters Children's Dishonesty: A Natural Experiment. Child Development, 82, 1751-1758. https://doi.org/10.1111/j.1467-8624.2011.01663.x

Teven, J. J. (2007). Teacher Caring and Classroom Behavior: Relationships with Student Affect and Perceptions of Teacher Competence and Trustworthiness. Communication Quarterly, 55, 433-450. https://doi.org/10.1080/01463370701658077

Teven, J. J., \& McCroskey, J. C. (1997). The Relationship of Perceived Teacher Caring with Student Learning and Teacher Evaluation. Communication Education, 46, 1-9. https://doi.org/10.1080/03634529709379069

Theoharis, D., \& Bekiari, A. (2016a). The Influence of Mathematics and Learning Environment in Verbal Aggressiveness and Interpersonal Relations: A Dynamic Analysis of Social Networks. In International Mathematical Society (Ed.), Proceedings of the 8th Congress International Mathematical Society (pp. 415-428). Berlin: International Mathematical Society.

Theoharis, D., \& Bekiari, A. (2016b). Social Networks Analysis of Centrality: Case Study in Leadership Networks. In Greek Mathematical Society (Ed.), Proceedings of the 33nd Congress Greek Mathematical Society (with International Participation) (pp. 250-260). Athens: Greek Mathematical Society.

Theoharis, D., \& Bekiari, A. (2017a). Applying Social Network Indicators in the Analysis of Verbal Aggressiveness at the School. Journal of Computer and Communications, 5, 169-181. https://doi.org/10.4236/jcc.2017.57015

Theoharis, D., \& Bekiari, A. (2017b). Cumulative Hierarchy Analysis (Katz Centrality) on Leadership Networks of Learning Communities. In International Mathematical Society (Ed.), Proceedings of the 9th Congress International Mathematical Society (pp. 285297). Berlin: International Mathematical Society.

Theoharis, D., Bekiari, A., \& Koustelios, A. (2017). Exploration of Determinants of Verbal Aggressiveness and Leadership through Network Analysis and Conventional Statistics. Using School Class as an Illustration. Sociology Mind, 7, 27-43.

https://doi.org/10.4236/sm.2017.72003

Thomas, C. E., Richmond, V. P., \& McCroskey, J. C. (1994). The Association between Immediacy and Socio-Communicative Style. Communication Research Reports, 11, 107-114. https://doi.org/10.1080/08824099409359946

Thweatt, K. S., \& McCroskey, J. C. (1998). The Impact of Teacher Immediacy and Misbehaviors on Teacher Credibility. Communication Education, 47, 348-358.

https://doi.org/10.1080/03634529809379141

Waller, R., Gardner, F., Hyde, L. W., Shaw, D. S., Dishion, T. J., \& Wilson, M. N. (2012). Do Harsh and Positive Parenting Predict Parent Reports of Deceitful-Callous Behavior in Early Childhood? Journal of Child Psychology and Psychiatry, 53, 946-953. https://doi.org/10.1111/j.1469-7610.2012.02550.x

Walter, H. L., Anderson, C. M., \& Martin, M. M. (2005). How Subordinates' Machiavellianism and Motives Relate to Satisfaction with Superiors. Communication Quarterly, 53, 57-70. https://doi.org/10.1080/01463370500056051

Wanzer, M. B., \& Frymier, A. B. (1999). The Relationship between Student Perceptions of Instructor Humor and Students' Reports of Learning. Communication Education, 1, 48-62. https://doi.org/10.1080/03634529909379152

Wheeless, V. E., \& Lashbrook, W. B. (1987). Style. In J. C. McCroskey, \& J. A. Daly (Eds.), Personality and Interpersonal Communication (pp. 243-272). Thousand Oaks, CA: 
SAGE Publications.

Wrench, J. S., \& Punyanunt-Carter, N. M. (2005). Advisor-Advisee Communication Two: The Influence of Verbal Aggression and Humor Assessment on Advisee Perceptions of Advisor Credibility and Affective Learning. Communication Research Reports, 22, 303-313. https://doi.org/10.1080/000368105000317599

Zagenczyk, T. J., Restubog, S. L. D., Kiewitz, C., Kiazad, K., \& Tang, R. L. (2014). Psychological Contracts as a Mediator between Machiavellianism and Employee Citizenship and Deviant Behaviors. Journal of Management, 40, 1098-1122.

https://doi.org/10.1177/0149206311415420

Submit or recommend next manuscript to SCIRP and we will provide best service for you:

Accepting pre-submission inquiries through Email, Facebook, LinkedIn, Twitter, etc. A wide selection of journals (inclusive of 9 subjects, more than 200 journals)

Providing 24-hour high-quality service

User-friendly online submission system

Fair and swift peer-review system

Efficient typesetting and proofreading procedure

Display of the result of downloads and visits, as well as the number of cited articles Maximum dissemination of your research work

Submit your manuscript at: http://papersubmission.scirp.org/

Or contact psych@scirp.org 